\title{
REVIEW
}

SEPTEMBER/ O CTOBER 1999

William R. Emmons is a research economist and Frank A. Schmid is a senior research economist at the Federal Reserve Bank of St. Louis. Robert Webb and Marcela Williams provided research assistance.

\section{Credit Unions and the Common Bond}

\author{
William R. Emmons and \\ Frank A. Schmid
}

ooperative financial institutions have their roots in 19th century Europe, appearing first in the U nited States during the early 20 th century. Cooperative financial institutions are ubiquitous in both developed and developing countries today, posing something of a puzzle in the former group of countries where one might have expected corporate financial institutions with professional management and sophisticated capital-market oversight to have displaced them. This has not occurred, however, as some groups of cooperative financial institutions in developed countries are holding steady or even increasing their market shares. In the United States, the most prominent types of cooperative financial institutions today are mutual savings and loans, mutual savings banks, mutual insurance companies, and credit unions.

Credit unions are regulated and insured financial institutions dedicated to the saving, credit, and other basic financial needs of selected groups of consumers. By law, credit unions are cooperative enterprises controlled by their members- under the principle of "one-person one-vote." In addition, credit union members must be united by a "common bond of occupation or association, or (belong) to groups within a well-defined neighborhood, community, or rural district" (Supreme Court, 1998, p. 2, quoting from the Federal Credit Union Act of 1934).

Despite the rather low profile and mundane operations of the vast majority of credit unions, these institutions have long been a source of controversy in the United States. Public awareness of this long-simmering debate was piqued recently by a Supreme Court case pitting commercial banks against credit unions and their federal regulator (Supreme Court, 1998). The Court found in favor of banks in this case, ruling that the federal credit-union regulator, the $\mathrm{N}$ ational $\mathrm{Credit} U$ Union Administration, must cease granting federally chartered credit unions the right to combine multiple common bonds (fields of membership) within a single institution. Less than six months later, however, President Clinton signed into law new legislation that essentially reversed the Supreme Court's ruling.

This paper provides background on credit unions and the debate they have spurred in the United States. In addition, we present new evidence relevant to the credit-union debate concerning fields of membership (common bonds). Our analysis is based on a theoretical model of credit-union formation and consolidation. Using an extensive dataset and a nonlinear empirical approach, we find that creditunion participation rates generally decline as the group of potential members becomes larger, holding all el se equal. That is, the larger the pool from which a singlegroup credit union can draw, the less effective it is in attracting members.

We also provide new evidence on two more general banking policy issues. First, we find evidence to support the structureconduct-performance paradigm of local banking competition. This is the prediction, derived from theoretical considerations, that more concentrated markets ultimately lead to higher prices and lower quantities. Policymakers have used this paradigm extensively when justifying intervention in the market for corporate control in financial services. Using the Herfindahl index calculated for local bank deposit market shares as a measure of local 
market structure, we find that higher levels of market concentration are associated with higher participation rates at credit unions. This is consistent with the notion that banking competition is weaker in more concentrated markets, which increases the attractiveness of credit unions.

The second banking policy issue we address is that of possible scale economies among financial institutions. Our empirical results indicate that credit unions generally encounter significant scale economies, whether scale is measured by the log of total assets or by the log of the number of credit-union members. The latter finding, however, applies only to relatively large credit unions.

It is important to point out several limitations of this study. As in all empirical investigations, we can describe relationships in the existing data but we cannot predict exactly how these relationships would appear under a different set of operating conditions. For example, an extended period of growth by many credit unions could alter the extent of scale economies that exist. Similarly, significant changes in credit-union regulation might result in different empirical regularities than those identified here. It also is important to keep in mind that we abstract from managerial agency problems in credit unions in this article (see Emmons and Schmid, 1999, for an extensive discussion of this issue). Finally, it is hazardous to draw conclusions about public policy toward credit unions on the basis of this rather narrowly focused investigation. We hope to provide insights into the effects of common-bond requirements, not to provide a comprehensive framework for evaluating competition in the financial-services sector as a whole.

The paper is organized as follows: The first section provides some institutional and historical background on credit unions, while the second section outlines the current credit-union debate in the United States. The third section develops a theoretical model of credit-union formation and consolidation. The model stresses the countervailing influences on participation rates of (1) scale economies in production, and (2) decreasing withingroup membership affinity as a credit union grows. The model provides intuition for why the number of common bonds within a credit union might be important for their formation and growth. The third section also describes a simulation of the theoretical model that can be used to generate some comparative-static results. The fourth section briefly describes the dataset and the econometric methods we employ in analyzing federally chartered occupational credit unions. The fifth section presents our empirical results, and the sixth section draws conclusions. An appendix describes the data we use.

\section{BACKGROUND ON CREDIT UNIONS}

This section provides some institutional background to help motivate the theoretical and empirical analyses later in the article. The key points this section seeks to illuminate are the restrictions on credit-union expansion and the arguments that have been made to support or oppose these restrictions. The sections that follow investigate the extent to which the common-bond requirement acts as a binding constraint on credit-union operations.

\section{O verview of Credit Unions in the United States}

Credit unions numbered 11,392 at year-end 1996, serving some 70 million individual members (U.S. Treasury, 1997, p. 15). At the same time, there were 11,452 commercial banks and thrift institutions ( savings and loan associations and mutual savings banks). Credit-union assets were only $\$ 327$ billion, compared to $\$ 5,606$ billion held by commercial banks and thrifts (U.S. Treasury, 1997, p. 21). A more direct standard of comparison might be community banks and thrifts, however. At year-end 1996, there were 7,049 community banks and thrifts (defined as all federally insured banks and thrifts with less than $\$ 100$ million in assets) holding 
combined assets of $\$ 324$ billion (U.S. Treasury, 1997, p. 21). A comparison of credit unions and community banks and thrifts is particularly meaningful because institutions of both types are relatively focused institutions, and hence, are unable to grow beyond certain limits. For example, a single-employer occupational credit union is authorized to serve only the employees of the sponsoring firm and their immediate relatives, who may total no more than a few hundred people. A community bank or thrift may operate in only one geographical area. In addition, credit unions are restricted in the types of financial services they may provide, with traditional consumer financial services at the core of virtually all credit unions' activities. Community banks and thrifts may offer a similar array of services.

Both federal and state agencies grant credit-union charters. Regardless of the type of charter they hold, the deposits (or technically, "shares") of virtually all credit unions are now federally insured by the National Credit Union Administration (NCUA). Federal credit unions are regulated by the NCUA while state-chartered credit unions are regulated by an agency of the chartering state.

Of the 7,068 federally chartered institutions at year-end 1996, about three quarters were occupational credit unions (U.S. Treasury, 1997, p. 19). ${ }^{1}$ In an occupational credit union, one or more firms sponsor a credit union, sometimes providing office space, paid time off for volunteer workers, and perhaps other forms of support. The remaining federal credit unions were either single-group associational or community credit unions, or multiple-group credit unions with predominantly associational, community, or more than one type of membership (i.e., several groups that span the usual classifications).

By size, most credit unions ( 65 percent of federally insured institutions) had less than $\$ 10$ million in assets (U.S. Treasury, 1997, p. 19). Large credit unions exist, however, and they are an important part of the sector. For example, the 11 percent of credit unions with more than $\$ 50$ million in assets (1,284 institutions) accounted for 74 percent of total credit-union assets.

Credit unions play a limited role in the U.S. financial system, catering to the basic saving, credit, and other financial needs of well-defined consumer groups. More than 95 percent of all federal credit unions offer automobile and unsecured personal loans, while a similar proportion of large credit unions (more than $\$ 50$ million in assets) al so offer mortgages; credit cards; loans to purchase planes, boats, or recreational vehicles; ATM access; certificates of deposit; and personal checking accounts (U.S. Treasury, 1997, p. 23). Very small credit unions typically offer a limited range of services, are staffed by membervolunteers, and are likely to receive free or subsidized office space. Larger credit unions offer a broader array of services. They may employ some full-time workers, including the manager, and are more likely to pay a market-based rent for office space.

Historically, members of credit unions were drawn from groups that were underserved by traditional private financial institutions; these consumers tended to have below-average incomes or were otherwise not sought out by banks. While credit-union members today still must share a common bond to be eligible for membership, the demographic characteristics of credit-union members have become more like the median American. While only 1 percent of the U.S. adult population aged 18 or over belonged to a credit union in 1935, some 33 percent of the adult population had joined by 1989 (American Bankers Association, 1989, p. 29). Subsequent strong growth of new credit-union charters has increased that proportion. ${ }^{2}$

According to a credit-union survey in 1987, 79 percent of all Americans who were eligible to join a credit union had done so (American Bankers Association, 1989, p. 29). Given the prominent role of occupational credit unions, a majority of members are in the prime working ages of 25-44 (American Bankers Association, 1989, p. 30). Perhaps surprisingly, given the origins of credit unions, current members are overrepresented in upper-middle

\footnotetext{
1 We concentrate on federally chartered credit unions because the NCUA does not vouch for the accuracy of data provided by state-chartered credit unions, which report directly to their state's regulatory authorities.

2 The estimated 70 million current credit-union members represent a bit more than 34 percent of the 1996 U.S. population over 16 years of age numbering 204 million (U.S. Census Bureau, <http:/ / www.census.gov>).
} 
income strata, defined as household incomes between $\$ 30,000$ and $\$ 80,000$ in 1987. Overall, it appears that credit unions, banks, and thrifts are more direct competitors today than when credit unions first appeared.

\section{A Brief Legislative History of Credit Unions in the United States}

The predecessors of American credit unions were cooperative banking institutions of various sorts in Canada and Europe during the 19th century. The first credit union in the United States was formed in Manchester, New Hampshire, in 1909 (U.S. Treasury, 1997, p. 15). Soon thereafter, M assachusetts created a charter for credit unions. The credit-union movement swept across the U nited States from there, meeting with particular success in the $\mathrm{New}$ England and upper Midwestern states.

These early cooperative financial institutions often had a social, political, or religious character in addition to their explicit economic function. While the social and political aspects of the cooperative movement were acknowledged and accepted by the United States Congress, the Federal Credit Union Act (FCUA) of 1934 was focused more narrowly on the economic potential of credit unions.

The legislation itself was modeled closely on state credit-union statutes that had appeared during the early decades of the 20th century in the N ortheast and upper Midwestern states. The FCUA clearly reflected Congressional intent to create a class of federally chartered financial institutions that would operate in a safe and sound manner:

... the ability of credit unions to "come through the depression without failures, when banks have failed so notably, is a tribute to the worth of cooperative credit and indicates clearly the great potential value of rapid national credit union extension." (Supreme Court, 1998, p. 17, citing the FCUA, S.Rep. No. 555.)
The likelihood that federal credit unions would serve consumers not served by banks was an additional element in Congressional deliberations:

Credit unions were believed to enable the general public, which had been largely ignored by banks, to obtain credit at reasonable rates. (Supreme Court, 1998, p. 17.)

Partly because credit unions are mutual associations, they were not subjected to federal taxation as were shareholder-owned commercial banks and thrift institutions. Mutuality cannot be the only reason why credit unions are not taxed, however. Other mutually owned enterprises are subject to taxation. As for the benefits of tax exemption, credit unions (or any other firm) could avoid paying taxes by paying out all "profits" to members in the form of lower borrowing rates or higher deposit rates. The real importance of the tax exemption is that credit unions can retain earnings tax free. Advocates argue that this is justified because credit unions cannot raise equity in a public offering, so they must be able to build capital internally.

It is clear from the legislative history surrounding the passage of the FCUA in 1934 that Congress saw the common-bond requirement as critical to the success of credit unions:

The common bond requirement "was seen as the cement that united credit union members in a cooperative venture, and was, therefore, thought important to credit unions' continued success. ..."

"Congress assumed implicitly that a common bond amongst members would ensure both that those making lending decisions would know more about applicants and that borrowers would be more reluctant to default." (Supreme Court, 1998, pp. 17-18, citing 988 F.2d, at 1276.)

The subsequent history of credit unions in the United States largely has fulfilled the promise envisioned by 
Congress in 1934. Credit unions have grown and spread across the country. Although hundreds of individual credit unions failed during the 1980 s and early 1990s, the National Credit Union Insurance Fund (NCUSIF, formed in 1970) avoided accounting insolvency - in marked contrast to the Federal Savings and Loan Insurance Corporation and the Bank Insurance Fund of the Federal Deposit Insurance Corporation (Kane and Hendershott, 1996). Credit unions control a small but growing share of household deposits, and some of our empirical results indicate that they may play a role in maintaining a high level of retail banking competition in some local markets.

\section{THE CURRENT CREDIT- UNION DEBATE}

The special status and comparative success of credit unions in recent decades, coinciding as it has with a period of stress on thrift and commercial-banking institutions, has led to political conflicts between advocates of credit unions and banks. This conflict reached its high point in a series of court decisions culminating at the U.S. Supreme Court in October 1997. The particular case at issue involved the AT\& T Family Credit Union and the NCUA's interpretation of the 1934 FCUA allowing multiple common bonds of membership. Brought by several banks and the American Bankers Association, the case was ultimately decided in February 1998 (on a 5-4 decision) in favor of the banks who sued to stop the NCUA from granting more multiple-group credit-union charters. The bankers' victory was short-lived, however, as Congress almost immediately drafted new legislation that enables credit unions to continue growing much as before-including multiple common bonds within a single credit union. The shaded insert summarizes the key provisions of the Act.

Attacks on credit unions have come from a wide range of viewpoints, the proponents of which have wielded sometimes contradictory arguments. Some of the arguments used in the recent Supreme Court decision concerning the role of the common-bond requirement in credit unions reflect the unsettled nature of the debate. We focus on two strands of the credit-union debate here, namely the arguments stressing inefficient governance structures on the one hand and unfair competition on the other.

Some have argued that credit unions are inherently inefficient due to their onemember one-vote governance structure. One might expect decision-making in a credit union to be of poor quality due to a lack of professionalism (i.e., volunteer managers and workers), free-riding of members in monitoring the management, and weak incentives for members to intervene when action is needed to correct specific problems or deficiencies. ${ }^{3}$ According to this argument, credit unions may waste scarce resources and they may eventual ly impose significant costs on individual sponsoring firms or the economy as a whole.

The second prominent line of argument aimed at credit unions takes a nearly opposite view of their organizational effectiveness. This view presumes that credit unions operate efficiently enough to offer consistently better terms on savings and credit services than those offered by commercial banks and thrifts. Bank and thrift managers and owners often present this point of view in public discourse. To be sure, those arguing that credit unions represent unfair competition ascribe some or all of their competitive advantages to subsidies such as their taxexempt status or sponsor subsidies rather than inherent efficiency.

Proponents of the first view - that credit unions are inherently inefficienthave a difficult time explaining why the number of credit unions and credit-union members continues to grow, and why members express high levels of satisfaction with the services they receive. If most credit unions were very inefficient, one might expect their members to become disaffected and their role in the financial system to diminish over time.

\footnotetext{
3 Free-riding is when members choose not to exert monitoring effort because they assume someone else will do it for them.
} 


\section{THE CREDIT UNION MEMBERSHIP ACCESS ACT}

President Clinton signed the Credit Union Membership Access Act on August 7, 1998, following approval in the Senate on July 28 and in the House of Representatives on August 4. The act substantially reverses a Supreme Court ruling handed down on February 25,1998 , that would have barred federally chartered credit unions from accepting multiple membership groups, each with its own common bond.

This landmark credit-union legislation represents a major defeat for the top lobbying group representing commercial banks, which had argued successfully at the Supreme Court that credit unions with multiple common bonds violated both the letter and the spirit of federal legislation dating from 1934. The subsequent legislative response in support of multiple common bonds at credit unions was swift and overwhelming, passing both chambers with large majorities.

The act contains three provisions upholding the rights of federal credit unions to serve membership groups encompassing multiple common bonds. First, all federal credit unions that already included multiple common bonds before February 25, 1998, were allowed to continue operating without interruption. Second, all federal credit unions were given the right to accept additional membership groups with multiple common bonds so long as the relevant groups have fewer than 3,000 members. Third, the act gives the $\mathrm{N}$ ational Credit Union Administration the right to grant exemptions to the 3,000-member limit under certain circumstances, such as when the group in question could not reasonably support its own credit union.

The act also:

- Requires annual independent audits for insured credit unions with total assets of $\$ 500$ million or more.

- Authorizes and clarifies a federally insured credit union's right to convert to a mutual savings bank or savings association without prior NCUA approval.

- Limits business loans to members to 12.25 percent of total assets.

- Establishes new capital standards for insured credit unions similar to those enacted for banks and thrifts in 1991.

- Gives the NCUA authority to base deposit-insurance premiums on the reserve ratio of the insurance fund.

- Directs the Treasury to report to Congress on differences between credit unions and other federally insured financial institutions, including the potential effects of applying federal laws-including tax laws- to credit unions.

Hailing the new legislation, President Clinton said, "This bill ensures that consumers continue to have a broad array of choices in financial services... .and [makes] it easier for credit unions to expand where appropriate." M eanwhile, a spokeswoman for the American Bankers Association termed it "ironic" that the bill was presented as a measure to protect credit unions because in the long run, she said, it will dilute them, turning them into larger and larger institutions.

Source: BNA Banking Report, "House Passes Credit Union Bill; Clinton Wastes No Time Signing It," August 10, 1998, Vol. 71, N o. 6.

On the other hand, proponents of the second view- that credit unions are unfair competitors due in part to subsidiescannot explain easily why credit-union sponsors and governments are such strong supporters of credit unions. It is hard to understand how large net subsidies could be delivered to credit-union members over 


\section{REVIEW}

SEPTEMBER/ O CTOBER 1999

time without more opposition arising from constituencies that might be paying the subsidies, such as shareholders or employees who do not belong to their firm's occupational credit union, or taxpayers who belong to no credit union. In fact, the most vocal complaints about alleged subsidies for credit unions are heard from banks and thrifts, whose resentment of credit-union competition could be expected even if there were no subsidies flowing to credit unions.

Ironically, the juxtaposition of these two lines of attack against credit unions appeared in the argumentation of the Supreme Court majority that decided the AT \& T Family Credit Union case in favor of commercial banks. At one point in its opinion, the majority cited the legislative history surrounding the 1934 Federal Credit Union Act as support for the view that credit unions are a fragile-even flawed-type of institution, reasoning that:

Because, by its very nature, a cooperative institution must serve a limited market, the legislative history of Section 109 demonstrates that one of the interests "arguably... to be protected" by Section 109 is an interest in limiting the markets that federal credit unions can serve. (Supreme Court, 1998, footnote 6, pp. 8-9.)

Thus, a credit union would become inefficient if it grew beyond its "limited market," as defined by its common bond.

At a different point in its opinion, however, the majority accepted the argument that credit unions with multiple groups of members would be more formidable competitors to banks and thrifts than single-group institutions. The majority argued that an expansive interpretation of the 1934 Act "would allow the chartering of a conglomerate credit union whose members included the employees of every company in the United States (1998, p. 4)." In other words, credit unions would overwhel $m$ banks and thrifts unless otherwise constrained.
The irony is, of course, that the argumentation based on the reductio ad absurdum of a hypothetical "congl omerate credit union" did not mention the legislative history of the 1934 Act, which had essentially predicted that such a huge credit union would not have been a safe and sound financial institution, nor consequently a viable one in the long run.

\section{THE MODEL AND \\ SIMULATION}

How should policymakers think about credit unions? Are they relics of a bygone era, propped up by subsidies and distorting financial-sector competition? Or, are they efficient and focused financial institutions that could, if unleashed, eventually dominate some or all of the retail financial landscape? We do not seek to answer these emotionally charged questions directly. Instead, we focus on the more limited question of what effect the common-bond restriction exerts on creditunion formation and consolidation. In a sense, we are merely attempting to answer the question, "Does the common-bond requirement constrain the existence or growth of credit unions?" We hope that our insights may contribute to a better understanding of the larger policy questions mentioned above.

In this section we present a model of credit-union formation and consolidation. We then describe the results of a simulation of the model. Subsequent sections of the paper discuss testable hypotheses emerging from the model, the data we examine, and empirical results.

\section{The Model}

We take for granted that credit unions typically are small; that they encounter operating economies of scale as they expand from a very small base of members and assets; and that they face direct competition from banks. The key trade-off we model is between decreasing affinity among members as the potential membership grows (i.e., as a given common bond is 


\section{Figure 1}

\section{Linear City with Three Common Bonds of Occupation}

Households employed by firm $A$

Households employed by firm $B$

AAAAAAAAAAAAAAAAAAAAAABBBBBBBBBBBBBBBB

0 - - - - - - - - Preferences for Banking Services - - - - - - $\bullet 1$ CCCCCCCCCCCCCCCCCCCCCCCC

Households employed by firm $\mathrm{C}$

extended to more people) - making a credit union less effective- versus the increasing scale economies that come with a larger base of members and assetsmaking a credit union more effective. We show that the ability of credit unions to expand by adding multiple common bonds to their membership affects this trade-off in an important way.

We examine a Hotelling (1929) economy consisting of a "city" that lies on a straight line of unit length. The city's length is covered by a continuum of households. The location of each household corresponds to its preferences for banking services. In particular, each household demands exactly one unit of banking services but the nature of desired services differs among households. Preferences in the real world are, of course, multidimensional, encompassing tastes for different menus of financial services, different levels of service, or different locational preferences. We assume for the sake of simplicity, however, that a household's preferences for banking services can be represented in terms of a single index running from zero to one. Figure 1 depicts the linear-city model.

Because we are interested only in the formation and consolidation of credit unions, we assume that credit unions are scarce (or differentiated) while commercial banks are ubiquitous (or uniform). In other words, consumption of credit-unionprovided financial services takes place at the point on the unit interval where a credit union is located, while commercial-bank services are available at a fixed price at any point on the line. This assumption makes household preferences critical for the existence of and participation in credit unions while maintaining the realistic assumption that commercial banks provide an alternative to credit unions (and vice versa).

We assume that the entire city (i.e., every point on the line) is covered by at least one household and at most two households. Without loss of general ity, we assume that all points covered by two households are arrayed continuously from zero upward towards, but potentially short of, one on the unit interval. For expositional purposes, we will refer to the households that inhabit the completely covered zero-to-one interval as being above the line and all others as below the line. Thus, two households that possess identical locations (preferences) are said to be "back-to-back" households.

Households are further grouped by affinity, or common bonds. For tractability, we discuss occupational common bonds and limit the number of employers in the economy to three. Each household located above the line contains an employee of either firm A or firm B (but not both). Because all households in employee group A share a common bond, they are located in a contiguous segment of the line that does not overlap the domain of employee group B. All households below the line contain employees of firm C. Each employer may sponsor a credit union, although, as we will see, not all will do so.

We examine two periods (or regimes), differentiated according to the permissibility of forming credit unions with multiple common bonds. All households are born at the start of period 1 and live through the end of period 2. Each household needs to consume one unit of banking services in each period. These services can be provided by an occupational credit union or by a bank in either period.

At the beginning of the first period, households find themselves arrayed along the city's unit interval. The lengths of the firm- $A$ and firm- $C$ segments are distributed as uniform random variables 
on the $[0,1]$ interval. The length of the firm- $B$ segment is one minus the length of the firm-A segment.

Suppose, first, that each of the three employers sponsors a credit union (in the simulation below, not all firms necessarily sponsor a credit union). All credit unions are restricted to a single employee group during the first period. Each credit union has a life span of one period. The credit unions have idiosyncratic technologies for producing banking services. In particular, each credit union i operates with fixed costs $f_{i}=f_{a}+f_{b} e_{i}$, where $f_{a}$ and $f_{b}$ are common to all credit unions and $e_{i}$ is an i.i.d. uniform random variable. In addition, each credit union faces constant marginal costs of $v$ per unit of banking services provided. Thus, the cost function of credit union $i$ is $c\left(m_{i}\right)=f_{a}+f_{b} e_{i}+v m_{i}$, where $m_{i}$ is the number of actual members in the credit union, and $i=A, B$, or $C$. An important feature of this cost function is that average costs, $\mathrm{C}\left(\mathrm{m}_{\mathrm{i}}\right) / \mathrm{m}_{i}$, are declining in the number of members the credit union is able to attract.

At the beginning of period 1 , households vote on the credit-union management team for that period. Voting is costless, the onehousehold one-vote principle applies, and side payments among households are permitted (to allow those with strongly held preferences to "buy" the votes of those with weaker preferences). This implies, by virtue of the "value maximization principle," that the competitive outcome maximizes social welfare (Milgrom and Roberts, 1992, pp. 36-37). The potential members choose a management team that locates the credit union to minimize the sum of member "travel costs" (which are described in the following paragraph). It is clear that the credit union will locate in the center of the preference spectrum of all potential members because we assume that travel costs are quadratically increasing in the distance between member households and the credit union.

Credit-union services are offered at the price $p_{i}$ to all potential members of a credit union (i.e., employees of the relevant firm). The price equals the credit union's

\section{Figure 2}

Travel Costs Facing Households Employed by Firms A and B

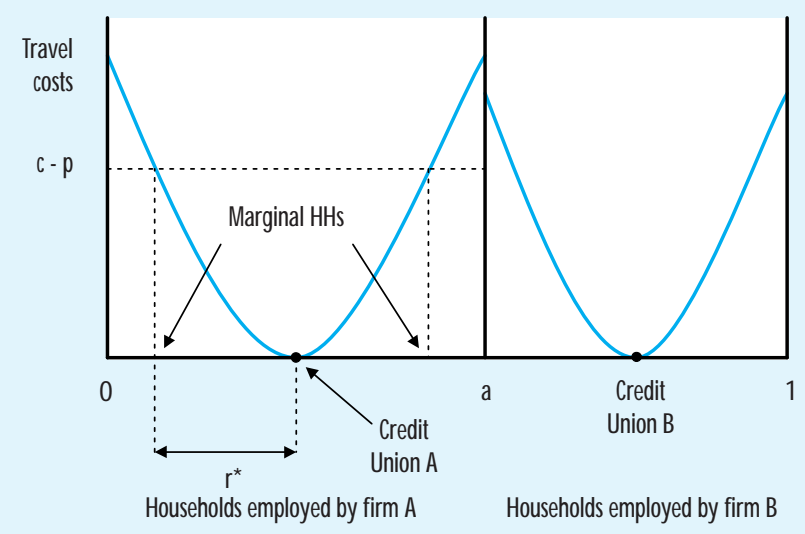

average costs $\left(A C_{i}\right)$ because credit unions are not-for-profit institutions. Households face marginal costs of $t \times r$ per unit of distancer when travelling to a credit union with $t$ being a travel-cost parameter. This is because the credit union's banking services are (in general) not identical to a given household's preferences (i.e., location on the line). The cost of using credit union i at a distance $r_{j}$ from household $j$ 's location is $(t / 2) r_{j}^{2}$. Each household al so can access banking services from a commercial bank at a constant price c. Together, these assumptions imply that the membership of credit union i will comprise all households $j$ within the potential membership for which the following inequality holds (see Figure 2):

$$
\frac{t}{2} r_{j}^{2} \leq c-p_{i}
$$

In particular, the marginal-i.e., most distant- households will be the ones (on either side of the credit union) for which the expression holds at equality:

$$
\frac{t}{2} r^{* 2}=c-p_{i} .
$$

As Figure 2 illustrates, not every potential member joins the credit union. A household relatively far from the credit union (at a distance greater than $r^{*}$ ) buys banking services from a commercial bank instead. The number of members credit 


\section{Figure 3}

\section{Demand and Supply Curves for Credit-Union Services}

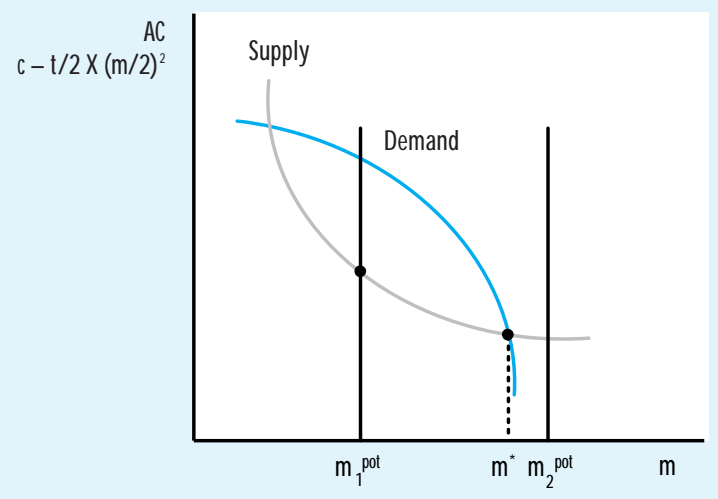

\section{Figure 4}

\section{A Case in Which No Credit Union Exists}

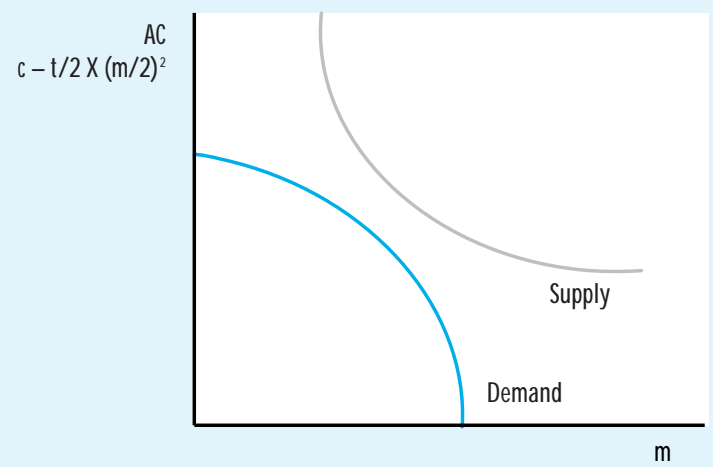

union i attracts is therefore $2 r *$, which we denote $\mathrm{m}^{*}$.

Because the average cost as a function of the number of credit-union members, $m$, is $(f+v m) / m$, and price must be equal to average cost, we now obtain an expression relating the distance between the marginal member and the credit union, $r^{*}$, and the optimal number of members in the credit union, $\mathrm{m} *$ :

$$
c-\frac{t}{2} r^{* 2}=\frac{f+v m^{*}}{m^{*}}
$$

But we know that $r^{*}=m^{*} / 2$, so we can substitute in equation 1 for $r^{*}$ to obtain a cubic expression that determines the optimal number of credit-union members, $\mathrm{m}^{*}$, expressed in terms of the demand-side parameters $c$ and $t$ ( price of commercialbanking services and the travel-cost parameter, respectively), as well as the supply-side parameters $f$ and $v$ (fixed and marginal costs of credit-union production of financial services, respectively):

$$
c-\frac{t}{2}\left(\frac{m^{*}}{2}\right)^{2}=\frac{f+v m^{*}}{m^{*}} .
$$

The economic interpretation of Equation 2, the optimality condition, is straightforward. The left-hand side represents the demand curve for credit-union services, while the right-hand side represents the average-cost curve of a credit union. Credit unions are not-for-profit institutions, so their average-cost curves also are their supply curves. A downward-sloping supply curve indicates that scale economies exist in the range we consider (see Figure 3 ). For $m^{\text {pot }}>m^{*}$, where $m^{\text {pot }}$ is the potential membership of the credit union, we obtain an interior solution. In other words, the participation rate- the fraction of the potential membership that chooses to join the credit union-is lower than one. For $m^{\text {pot }} \leq m^{*}$, on the other hand, the participation rate is equal to one because all potential members choose to join.

Notice that, if the domain of potential members of a credit union is too small, the supply and the demand curves may not intersect. In this case, the credit union cannot operate because there is no positive number for $\mathrm{m}^{*}$ that satisfies equation 2 (see Figure 4).

The second period of the model corresponds to a regime in which the law allows credit unions to serve groups of households united by different common bonds (e.g., employees of both firms $A$ and $B$ ). A new management team must be selected at the beginning of period 2 to operate each credit union. New credit unions may be formed in which multiple occupational groups are included. In addition to single-employer credit unions, we now might see four other combinations of common bonds- 
a multiple-group credit union encompassing employees of firms:

- $A$ and $B$ (what we term an "A\& B" credit union) plus a single-group credit union serving employees of firm $C$;

- $A$ and $C$ (an "A\& C" credit union) plus a single-group credit union serving employees of firm $B$;

- $B$ and $C$ (a "B\& C" credit union) plus a single-group credit union serving employees of firm $A$; and

- $A, B$, and $C$ (an " $A \& B \& C$ " credit union).

As in period 1, none of these credit unions necessarily exists; the particular configuration of parameters will determine the outcome.

We allow for side payments so there is no path dependence as we go from period 1 to period 2 (i.e., period-2 results do not depend on period-1 outcomes). As in period 1 , the socially optimal combination of occupational groups is chosen. Also, the new credit unions will again be located in the center of the preference spectrums of their potential members. Before voting, all potential members of the various credit unions observe the (random) technology the new credit unions possess. These are drawn anew at the beginning of period 2 . We all ow the fixed costs of a multiplegroup credit union to deviate

systematically from the fixed costs of a single-group credit union. The fixed costs of a multiple-group credit union i amount to $\mathrm{f}_{\mathrm{i}}=\mathrm{f}_{\mathrm{a}}(1+\alpha)+\mathrm{f}_{\mathrm{b}} \mathrm{e}_{\mathrm{i}}$, with $\alpha>-1-\mathrm{f}_{\mathrm{b}} \mathrm{e}_{\mathrm{i}} / \mathrm{f}_{\mathrm{a}}$.

After the new credit unions have been established, each household either purchases one unit of banking services from the credit union or it buys them from a commercial bank. The economy ends after period 2.

Finally, we point out several comparative-static features of the model that follow standard intuition despite the existence of a downward-sloping supply curve. The two important demand-side parameters are $t$, the households' travel-cost parameter, and $c$, the cost of alternative banking services as provided by a commercial bank. Recalling Figure 3, which shows the supply curve of the credit union and the demand curve for its services, it is clear that as a household's travel costs rise, the demand for credit-union services declines. We interpret rising travel costs as an increase in the strength of a household's preferences for its ideal bundle of banking services. Such an increase causes the demand curve to shift downward, decreasing $m^{*}$. That is, the optimal size of the credit union declines. On the other hand, an increase in the price of commercial-bank provided financial services, c, shifts the demand curve up. This has the opposite effect on the optimal size of the credit union, increasing $\mathrm{m}^{*}$.

The important supply-side parameters of the model are $f$, the credit union's fixed cost, and v, the credit union's marginal cost of providing banking services. An increase in $f$ pushes up the supply curve of creditunion services, with the sharpest increase at low levels of membership. An increase in the marginal cost of credit-union production also translates into an upward shift of the supply curve. In both cases, the size of the potential membership required to achieve full participation increases.

\section{Simulation of the Model}

We simulate the model by drawing repeatedly (10,000 times) a set of five uniformly distributed random numbers from the $[0,1]$ interval. The first draw determines the length of the segment containing households with an employee of firm A. Recall that the length of the segment containing firm- $B$ households equals one minus the length of the firm-A segment. The second draw determines the length of the segment containing households with an employee of firm $C$. This determines the length of the line segment that is covered by two households. The last three random numbers enter the three (potential) credit unions' cost functions as stochastic elements of their fixed costs (denoted $e_{i}$ in the model description above, $i=A, B, C$ ). These random el ements in the credit unions' cost functions ensure that a "conglomerate" credit union consisting of the employees of all three firms is not degenerate- i.e., existing with probabilities of either zero or one. 
Recall that in the first period, all credit unions must consist of a single common bond. The first step in the formation of a credit union is a vote by the potential membership on the management team. Since side payments are allowed, the team that minimizes the sum of the travel costs of all potential members-i.e., which picks the most central location-will win. In a second step, all households decide whether to become members or to purchase financial services from a commercial bank.

We calculate the preferred outcome for each group of households in turn $(A, B$, and $C)$. The equilibrium solution for each employee group must be one of three possibilities: the credit union exists at a corner solution, in which all households participate; the credit union achieves an interior solution with a participation rate less than one; or the credit union does not exist. To compare the various outcomes, we calculate a welfare index for each group of households that is simply the sum of the production costs of the credit union (if it exists), the travel costs incurred by households that use credit unions, and the expenditures of households that obtain financial services from a bank, all multiplied by negative one ( to maintain the convention that a higher index value signifies higher social welfare):

(3) $-(f+m v)-\int_{0}^{r} \int_{0}^{*} \operatorname{tr} d r d r-\left(m^{\text {pot }}-m\right) c$.

In the second period, multiple-group credit unions are allowed. We iterate through the possible combinations by first allowing mergers between two given credit unions and forcing the third to operate independently (if it exists). Then we allow all three credit unions to merge. In each regime, households vote on the management team (i.e., choose the credit union's location). In particular, households choose between a team that would operate the credit unions independently and a team that would merge them. Because bribing is allowed, the team that maximizes the welfare index over all potential members will win. It is possible that a stand-alone credit union that could not exist on its own becomes part of a multiple-group credit union. The reason is that the post-merger credit union is able to spread its fixed costs over a larger membership. It also is possible that a credit union that could not exist on its own also is not viable as part of a multiple-group credit union. On the other hand, any employee group that is served by a credit union in period 1 also will be served by a credit union in period 2 because all mergers must be welfare-enhancing. That is, all options for operating credit unions with single common bonds available in period 1 still are possible after permitting multiple common bonds in period 2 .

Table 1 displays a summary of the simulation results. The table presents two measures of credit-union activity: the fraction of all employee groups served by a credit union and the fraction of households served by a credit union. When only single-employer credit unions are allowed (period 1), only 6 percent of the 30,000 simulated employers (A, B, and $C$ in each of 10,000 simulations) actually sponsor a credit union and only 4 percent of households actually belong to credit unions. Among households that are eligible to join a credit union, some 50 percent do so. All other households use commercial banks to obtain financial services. We have chosen parameter values to reflect the fact that single-group credit unions are relatively small and may not be viable for many employee groups.

The bottom part of Table 1 presents results when multiple-group credit unions are allowed ( period 2). It is clear that the permissibility of multiple common bonds dramatically increases the viability of credit unions. This is a general result in the sense that restricting credit union membership to one employee group is a binding constraint, the relaxation of which may increase the beneficial role of credit unions for employees. When two employee groups may be combined in a single credit union ( $A$ and $B, A$ and $C$, or $B$ and $C$ ), the fraction of employee groups in the economy served by a credit union rises to between 


\section{REVIEW}

\section{Table 1}

\begin{tabular}{|c|c|c|c|c|c|c|c|c|}
\hline & & \multicolumn{3}{|c|}{$\begin{array}{l}\text { Fraction of employee groups } \\
\text { served by... }\end{array}$} & \multicolumn{4}{|c|}{$\begin{array}{l}\text { Participation rates as } \\
\text { a fraction of... } 1\end{array}$} \\
\hline $\begin{array}{l}\text { Credit } \\
\text { Unions in } \\
\text { the Economy }\end{array}$ & & $\begin{array}{l}\text { (1) } \\
\text { Any Credit } \\
\text { Union }\end{array}$ & $\begin{array}{c}(2) \\
\text { A Single- } \\
\text { Group Credit } \\
\text { Union }\end{array}$ & $\begin{array}{c}(3) \\
\text { A Multiple- } \\
\text { Group Credit } \\
\text { Union }\end{array}$ & $\begin{array}{c}\text { (4) } \\
\text { All } \\
\text { Households }\end{array}$ & $\begin{array}{l}\text { (5) } \\
\text { Those } \\
\text { Households } \\
\text { Eligible to } \\
\text { Join a Single- } \\
\text { Group Credit } \\
\text { Union }\end{array}$ & $\begin{array}{l}\text { (6) } \\
\text { Those } \\
\text { Households } \\
\text { Eligible to } \\
\text { Join a } \\
\text { Multiple- } \\
\text { Group Credit } \\
\text { Union }\end{array}$ & $\begin{array}{c}\text { (7) } \\
\text { Those } \\
\text { Households } \\
\text { Eligible to } \\
\text { Join a Credit } \\
\text { Union } \\
\text { (weighted } \\
\text { average of } \\
5 \text { and 6) }\end{array}$ \\
\hline Period 1 & Welfare index & & & & & & & \\
\hline $\begin{array}{l}\text { Only single- } \\
\text { group credit } \\
\text { unions }\end{array}$ & $-23,951.89$ & 0.06 & 0.06 & ---- & 0.04 & 0.50 & -.-. & 0.50 \\
\hline Period 2 & $\begin{array}{l}\text { Increase in } \\
\text { welfare index }\end{array}$ & & & & & & & \\
\hline$A \& B, C$ & 53.09 & 0.14 & 0.04 & 0.10 & 0.04 & 0.50 & 0.31 & 0.40 \\
\hline$A \& C, B$ & $1,048.20$ & 0.50 & 0.03 & 0.47 & 0.37 & 0.48 & 0.77 & 0.74 \\
\hline$B \& C, A$ & 523.49 & 0.34 & 0.04 & 0.30 & 0.16 & 0.45 & 0.60 & 0.46 \\
\hline$A \& B \& C$ & $1,123.34$ & 0.49 & 0.01 & 0.48 & 0.30 & 0.58 & 0.41 & 0.42 \\
\hline $\begin{array}{l}\text { Optimal } \\
\text { Combination }\end{array}$ & $1,590.32$ & 0.94 & 0.02 & 0.93 & 0.43 & 0.54 & 0.56 & 0.56 \\
\hline
\end{tabular}

14 and 50 percent, while the fraction of households served by a credit union rises to between 4 and 37 percent, depending on the combination. When all three employee groups are allowed to combine in a single credit union ( $A$ and $B$ and $C$ ), the fraction of employee groups served by a credit union jumps to 49 percent, although only 30 percent of households are still served. ${ }^{4}$

Examination of column 6 indicates that multiple-group credit unions comprising groups $A$ and $B$ or $A, B$, and $C$ are characterized by relatively low participation rates. This reflects the fact that many members of employee groups $A$ and $B$ are located far from any multiple-group credit union, reducing their incentive to join. The credit union formed by employee groups $\mathrm{A}$ and $\mathrm{C}$ alone, on the other hand - which are located back-to-back - is characterized by a very high participation rate ( 77 percent of those eligible actually join). This is because the preferences of these two groups overlap.

In general, how likely households are to join credit unions does not depend primarily on whether multiple-group credit unions are allowed (see column 7, where the exception is the credit union comprising groups $\mathrm{A}$ and $\mathrm{C}$, the back-to-back case). In other words, participation rates in multiple-group credit unions are not necessarily higher. Rather, it is the fact that more credit unions are viable when multiple common bonds are allowed that is responsible for the expanded role of credit unions in the economy. A comparison
${ }^{4}$ Household segments not involved in a merger during the second-period simulations face the same economic situation as in the first period. Consequently, they come to the same decision during the second period of whether to operate a credit union as they did during the first period. 


\section{Figure 5}

\section{Participation Rates as a Function of Potential Membership \\ Participation Rate}

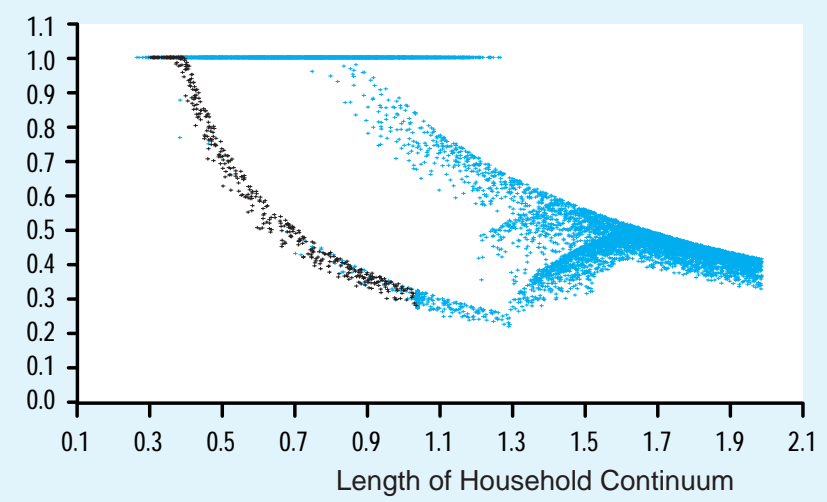

of columns 1 and 3 shows that newly viable multiple-group credit unions are indeed the key to greater credit-union access by households, as the lion's share of all credit unions in every possible configuration in period 2 include multiple common bonds.

The final row of Table 1 presents the social optimum, which is the welfare-maximizing combination of singleand multiple-group credit unions that is feasible in the economy. Multiple-group credit unions serve 93 percent of all employee groups in the social optimum, while single-group credit unions serve only 2 percent. Average household participation rates are similar across the two types of credit unions, with the multiplegroup average slightly higher.

The averages presented in Table 1 conceal two important features of credit unions in our model, however. Figure 5 is a scatterplot showing the participation rates of all the (optimally formed) credit unions from our 10,000 runs as a function of potential membership. The horizontal scale runs from about 0.1 (the minimum segment length needed to support a credit union under our baseline parameterization) to 2.0 (the sum of two unit-length segments, corresponding to the maximum potential membership of any multiple-group credit union). The two distinct downwardcurving sets of points represent the declining participation rates of singlegroup (the gray points in the lower curve, ending at 1.0) and multiple-group credit unions (the blue points), respectively. If we were to show each type of credit union plotted in Figure 5 in a separate chart, two important features would be obvious from the average participation rates shown in Table 1.

The first feature is that participation rates of multiple-group credit unions tend to lie above those of single-group credit unions for a given number of potential members. This points to the fact that multiple-group credit unions can be closer to the average member's preferences due to the existence of back-to-back households (i.e., households with different employers but identical preferences for banking services). This effect is due entirely to the households in employee group $C$ in our model, whose preferences overlap those of some households in other employee groups, most importantly group $\mathrm{A}$.

Figure 5 al so shows the second important feature of the model that is not revealed in the table- the downward slope of both main sets of points. Greater potential membership tends to generate lower participation rates. This al ways holds for single-group credit unions and for multiple-group credit unions that comprise "horizontally neighboring" membership groups only (i.e., groups A and B). Given the travel costs that represent preference heterogeneity among the potential membership, it is not surprising that credit unions that span a more heterogeneous set of households are able to attract proportionately fewer of them. For credit unions that comprise segments $B$ and $C$, participation rates initially fall with an increase in the membership base, then rise and later fall again. Credit unions that unite all three employee groups $(A \& B \& C$ credit unions) exhibit a similar pattern in terms of participation rates. For $A \& B \& C$ credit unions, a rise in the potential membership is due solely to an increase in the interval spanned by group $C$, which means an increase in the fraction of households located back-to-back. For back-to-back 


\section{PEVIEW}

SEPTEMBER/ O CTOBER 1999

\section{Table 2}

\begin{tabular}{|c|c|c|c|c|c|c|c|c|c|c|c|c|c|}
\hline \multirow[t]{2}{*}{ Column } & \multicolumn{3}{|c|}{$\begin{array}{l}\text { Parameter } \\
\text { Values }\end{array}$} & \multicolumn{6}{|c|}{$\begin{array}{l}\text { Number of times this configuration of } \\
\text { credit unions was optimal: }{ }^{1}\end{array}$} & \multicolumn{4}{|c|}{ Participation rates as a fraction of... ${ }^{2}$} \\
\hline & $\alpha$ & $t$ & c & $\begin{array}{c}(1) \\
A, B, C\end{array}$ & $\begin{array}{c}(2) \\
A \& B, C\end{array}$ & $\begin{array}{c}(3) \\
A \& C, B\end{array}$ & $\begin{array}{c}(4) \\
B \& C, A\end{array}$ & $\begin{array}{c}(5) \\
A \& B \& C\end{array}$ & $\begin{array}{c}\text { (6) } \\
\text { Number of } \\
\text { employee } \\
\text { groups not } \\
\text { served by a } \\
\text { credit union }\end{array}$ & $\begin{array}{c}\text { (7) } \\
\text { All House- } \\
\text { holds }\end{array}$ & $\begin{array}{c}\text { (8) } \\
\text { All House- } \\
\text { holds } \\
\text { Eligible to } \\
\text { Join a Credit } \\
\text { Union }\end{array}$ & $\begin{array}{l}\text { (9) } \\
\text { Those } \\
\text { Households } \\
\text { Eligible to } \\
\text { Join a } \\
\text { Single- } \\
\text { Group } \\
\text { Credit Union }\end{array}$ & $\begin{array}{c}\text { (10) } \\
\text { Those } \\
\text { Households } \\
\text { Eligible to } \\
\text { Join a } \\
\text { Multiple- } \\
\text { Group } \\
\text { Credit Union }\end{array}$ \\
\hline (1) & 0 & 22 & 1.6 & 746 & 168 & 4,452 & 1,168 & 3,466 & 7,959 & 0.43 & 0.56 & 0.54 & 0.56 \\
\hline (2) & 0 & 22 & 1.7 & 302 & 394 & 4,580 & 1,223 & 3,501 & 4,782 & 0.54 & 0.61 & 0.64 & 0.61 \\
\hline (3) & 0 & 24 & 1.6 & 926 & 99 & 4,436 & 1,169 & 3,370 & 8,793 & 0.40 & 0.55 & 0.50 & 0.55 \\
\hline (4) & 0.05 & 22 & 1.6 & 895 & 111 & 4,489 & 1,148 & 3,357 & 8,436 & 0.43 & 0.57 & 0.54 & 0.57 \\
\hline
\end{tabular}

credit unions of the type $A \& C$, the participation rate increases with a growing membership base if (and only if) the overlap of the intervals spanned by the two segments increases. If (and only if) the overlap shrinks with an increase in the potential membership, the participation rates shrink, too. To sum up, the overall effect of the size of potential membership on the participation rates depends on the relative importance of the various types of multiple-group credit unions.

Table 2 presents comparative-static results for changes in the parameters $t, c$, and $\alpha$ (the travel cost parameter, the price of banking services of commercial banks, and the parameter in the multiple-group credit unions' fixed costs, respectively). The first row restates the results of the benchmark simulation summarized in the last row of Table 1. Columns 1-5 show the number of times in the 10,000 runs of the simulation that each configuration of credit unions was optimal. The most frequently preferred configuration was a two-group credit union comprising employee groups A and C (column 3), the back-to-back solution. In this configuration, employees of firm B were sometimes served by a credit union and sometimes not; the feasibility of a credit union for employee group $B$ depends on the size of the membership base and the random technology of the potential credit union. The next most frequently preferred configuration involved a three-group credit union. Across all simulations, almost 27 percent of employee groups were left unserved by credit unions even though all mergers were chosen optimally (this figure is calculated from column 6 , which is divided by the total number of employee groups in the simulation, 30,000). It is apparent that participation rates of multiple group credit unions (column 10) are dragged down primarily by the relatively low participation rates in the credit unions with horizontally neighboring groups (i.e., credit unions $A \& B$ and $A \& B \& C$; recall the result from column 6 of Table 1 ).

The first comparative-static exercise we performed is summarized in the second row of Table 2. When the price of financial services offered by commercial banks rises, the fraction of employee groups as well as the fraction of households served by credit unions increases, as expected. From column 6 we know that only 16 percent of employee groups have no credit union after the higher cost of bank-provided services is imposed, while only 46 percent of households use a commercial bank 
(down from 57 percent in the benchmark case; see column 7). Interestingly, all of the multiple-group credit unions increasingly are preferred when banking services become more costly, while only the singlegroup credit unions become less likely to be optimal. A higher price for bankprovided services is predicted by higher banking concentration in the structureconduct-performance paradigm, and our comparative-static result demonstrates that credit unions are indeed likely to benefit from more concentrated banking markets.

The second comparative-static result we computed is summarized in the third row of Table 2. When the cost of travelling to a credit union is increased-intuitively, when preferences for banking services become more idiosyncratic or strongly held-both the fraction of employee groups served by credit unions and the participation rate of households decline (columns 6 and 7-10, respectively). Compared to the benchmark case, the number of single-group credit unions in optimal configurations increases (column 1). On the other hand, multiple-group credit unions appear somewhat less attractive (columns 2-5).

The last row of Table 2 displays our third comparative-static result. When the fixed costs of production are systematically higher for multiple-group credit unions than for single-group credit unions, the formation of multiple-group credit unions is less advantageous. Relative to the benchmark case displayed in row 1 , fewer groups of employees are served by credit unions (column 6). When they exist, credit unions with multiple-group charters have higher participation rates than in the benchmark case (column 10), which is due mainly to the higher representation of pure back-to-back credit unions (column 3). This leaves the overall household participation rate unchanged at the reported two-digit level of precision (column 7).

Taken together, the comparative-static results in Table 2 indicate that the optimal configuration of credit unions in the economy is sensitive to model parameters such as the market price of bank-provided financial services, the intensity of preferences for specific bundles of banking services, and the potential extra costs associated with multiple-group charters.

\section{Hypotheses}

We are now able to state several testable hypotheses that involve the determinants of the participation rate and the average operating costs (i.e., the cost ratio). First, we focus on participation rates at credit unions. Our maintained hypothesis is that a credit union is more successful in providing services to its constituency the less heterogeneous is its membership. This leads to our first testable hypothesis:

- HYPOTHESIS 1. A credit union's participation rate falls with the number of its potential members, all else held constant.

Another hypothesis concerns the effects of local banking-market conditions on credit-union participation rates:

- HYPOTHESIS 2. A credit union's participation rate rises with the level of concentration in the local banking market, all else held constant.

N ext we investigate the validity of our maintained assumption that credit unions face scale economies in production:

- HYPOTHESIS 3a. A credit union's cost ratio falls with the number of its potential members, all else held constant.

- HYPOTHESIS 3b. A credit union's cost ratio falls with its level of total assets, all else held constant.

Related questions include the effect of multiple-group charters on the cost ratio and the participation rate. Neither the model nor the simulation address the relationship between multiple common bonds and the cost ratio. As for the impact 
of multiple common bonds on the participation rate, the model and simulation results are ambiguous. Consequently, it is purely an empirical question how multiple-group credit unions affect operating costs and participation rates, holding all else constant.

\section{DATA AND EMPIRICAL METHODS}

We examine a subset of all federally chartered and federally insured occupational credit unions in 1996 (see the appendix for details on construction of the dataset and the variables we use). Table 3 provides a breakdown of our sample according to the type of membership group characterizing each credit union. The table distinguishes between credit unions with a single common bond and those with multiple common bonds. Credit unions sponsored by a single educational institution, for example, numbered 299 in our sample. Credit unions with a membership comprising multiple common bonds, most of which were educationally oriented, numbered 469 , and so on for the other membership types. Overall, 1,980 credit unions in our sample had a single common bond (41.8 percent of the sample) while 2,753 credit unions had multiple common bonds among the membership (58.2 percent).

In addition to data on individual credit unions, we collected three types of environmental variables. To control for differences in local economic conditions, we gathered levels and computed growth rates of real gross state product for each state. M easures of economic activity may capture systematic differences in demand for credit union services that we have not modeled explicitly. We also calculated the Herfindahl index of concentration of bank deposit shares in each credit union's local banking market, since concentration measures often are used to control for differences in the competitiveness of local markets. The index is calculated as the sum of the squared market shares of all participants in each local market. Third, we collected data on population density by county, which might be another factor

\section{Table 3}

Distribution of Credit Unions by

Type Of Membership (TOM)

\begin{tabular}{|c|c|c|}
\hline $\begin{array}{l}\text { Number of } \\
\text { Credit Unions }\end{array}$ & $\begin{array}{l}\text { TOM } \\
\text { Codes }^{1}\end{array}$ & Type of Membership \\
\hline 299 & 4 & Educational \\
\hline 37 & 5 & Military \\
\hline 392 & 6 & Federal, state, local government \\
\hline 744 & $10-15$ & Manufacturing \\
\hline 508 & $20-23$ & Services \\
\hline 469 & 34 & Multiple group - primarily educational \\
\hline 124 & 35 & Multiple group - primarily military \\
\hline 621 & 36 & Multiple group - primarily federal, state, local government \\
\hline 821 & $40-49$ & Multiple group - primarily manufacturing \\
\hline 718 & $50-53$ & Multiple group - primarily services \\
\hline \multicolumn{3}{|l|}{ Total: 4,733 } \\
\hline
\end{tabular}

in credit unions' competition with commercial banks.

We use a semiparametric model to allow the influence of the number of members and total assets on the dependent variable to be nonlinear. The parametric part of the model contains independent variables whose effects may be approximately linear, such as the Herfindahl index. In particular, we use a semiparametric model of a credit union's participation rate of the form:

$$
y_{i}=x_{p i} \times \beta_{p}+f\left(x_{i}\right)+\varepsilon_{i}, \quad i=1, k, n,
$$

where $y_{i}$ is the $i$-th observation of the dependent variable; $x_{p i}$ is a row vector consisting of the $i$-th observation of the explanatory variables of the linear (parametric) part of the model; $\beta_{p}$ is a column vector of the parameters of the linear part of the model; $x_{i}$ is a vector consisting of the $i$-th observation of the explanatory variables in the nonparametric part of the model; and ( $\varepsilon_{i}$ is the i-th realization of the error term. For details on this econometric approach, see the appendix in Emmons and Schmid (1999).

Our hypotheses are framed in terms of two different dependent variables, namely: 1) PARTICIPATION, the participation rate of those eligible to join the credit union, 


\section{Table 4}

\section{Descriptive Statistics ${ }^{1}$}

\begin{tabular}{lccccc} 
& Minimum & Median & Mean & Maximum & $\begin{array}{c}\text { Standard } \\
\text { Deviation }\end{array}$ \\
\hline $\begin{array}{l}\text { Participation Rate } \\
\text { (PARTICIPATION) }\end{array}$ & $3.050 \times 10^{-2}$ & $6.246 \times 10^{-1}$ & $6.142 \times 10^{-1}$ & 1 & $2.139 \times 10^{-1}$ \\
Cost Ratio (COST) & $6.268 \times 10^{-3}$ & $3.897 \times 10^{-2}$ & $4.088 \times 10^{-2}$ & $4.169 \times 10^{-1}$ & $1.739 \times 10^{-2}$ \\
Total Assets & $4.300 \times 10^{4}$ & $6.231 \times 10^{6}$ & $3.300 \times 10^{7}$ & $8.922 \times 10^{9}$ & $1.652 \times 10^{8}$ \\
Number of Members & $4.500 \times 10^{1}$ & $1.865 \times 10^{3}$ & $6.833 \times 10^{3}$ & $1.601 \times 10^{6}$ & $2.860 \times 10^{4}$ \\
Number of Potential Members & $7.500 \times 10^{1}$ & $3.193 \times 10^{3}$ & $1.432 \times 10^{4}$ & $2.032 \times 10^{6}$ & $5.540 \times 10^{4}$ \\
Herfindahl Index & $5.346 \times 10^{-2}$ & $1.966 \times 10^{-1}$ & $2.080 \times 10^{-1}$ & 1 & $9.469 \times 10^{-2}$ \\
& & & & &
\end{tabular}

defined as the number of actual members divided by the number of potential members as specified in the credit union's charter; and 2) COST, the credit union's total operating expenses divided by total assets. There are four independent variables of interest: the number of members (or the number of potential members when we examine participation rates); total assets (for the COST regression); the Herfindahl index of local bank-deposit concentration (HERF); and the indicator variable MULTGROUP, which is equal to one if the credit union has a multiplegroup charter and zero otherwise.

Membership (or potential membership) and total assets are included in the nonparametric part of both regression approaches. They are in logarithmic form and - to avoid simultaneity problems-are lagged by one period. The parametric part of the model includes the other two variables of interest, HERF and MULTGROUP. The parametric part also contains the following control variables: the credit union's home state's real gross state product per capita (REALGSPPC) in the PARTICIPATION regression; the log growth rate of real gross state product (GRREALGSP) in the COST regression; and indicator variables corresponding to the credit union's primary field of membership (in both regression approaches). Fields of membership include educational, military, government, manufacturing, and services. Because there is a constant included in the nonparametric part of the regression equation, we must drop one of the membership indicator variables; we chose the educational indicator variable for exclusion.

The variable REALGSPPC in the PARTICIPATION regression controls for preferences for banking services as they may vary with real income. In the COST regression, GRREALGSP serves as a measure for real growth, which is a main factor in the capacity utilization of credit unions. In the PARTICIPATION regression, the Herfindahl index is lagged to avoid simultaneity problems that may arise from the interaction between credit-union participation rates and concentration in the local banking market.

Table 4 presents descriptive sample statistics for the dependent and some of the independent variables. The participation rate among sample credit unions ranged from 3 percent to 100 percent, with the median at 62 percent. The median cost ratio was 3.90 percent, with a range of 0.63 to 41.70 percent of assets. Although this range may contain some extreme values, we retain all observations because all of them contain information. In addition, our locally weighted regression approach is somewhat robust to outliers. Total assets ranged from $\$ 43,000$ to $\$ 8.92$ billion, with the median credit 
union holding $\$ 6.23$ million in assets.

The number of actual and potential members ranged from 45 to 1.6 million and 75 to 2.03 million, respectively, while median actual and potential membership counts were 1,865 and 3,198 , respectively. Finally, Herfindahl indexes in relevant banking markets ranged from 0.0535 to 1.00 with a median value of 0.1966 (recall that the index is defined on the interval $((0,1])$.

\section{EMPIRICAL RESULTS}

Our results are presented in two sections corresponding to the dependent variable used. The first section discusses results from regressions using credit unions' participation rate while the second section reports results from regressions using credit unions' cost ratio.

\section{Participation Rates}

Hypothesis 1 relates the size of a credit union's potential membership to its participation rate. Regressions including PARTICIPATION use (the lagged value of the log of) potential members instead of actual members. Potential members are relevant for evaluating participation rates because all individuals eligible to join constitute the predetermined economic potential that each credit union seeks to exploit.

The series of plots presented in Figures 6-8 are "conditioning plots." The solid lines in Figures 6-8 are point estimates and the dashed lines indicate 90-percent confidence bounds. In each plot, one variable is held at its median value while the other variable (identified on the horizontal axis) is allowed to vary. The graph displays the impact of this independent variable on the level of the dependent variable. In other words, the slope of the graph at a particular point reflects the marginal impact of the independent variable at that point. The intercept is not identified in regressions of this type, so only vertical distances are meaningful (not the level itself). In sum, the key to interpreting these graphs is

\section{Figure 6}

\section{Participation Rate - Number of Potential Members}

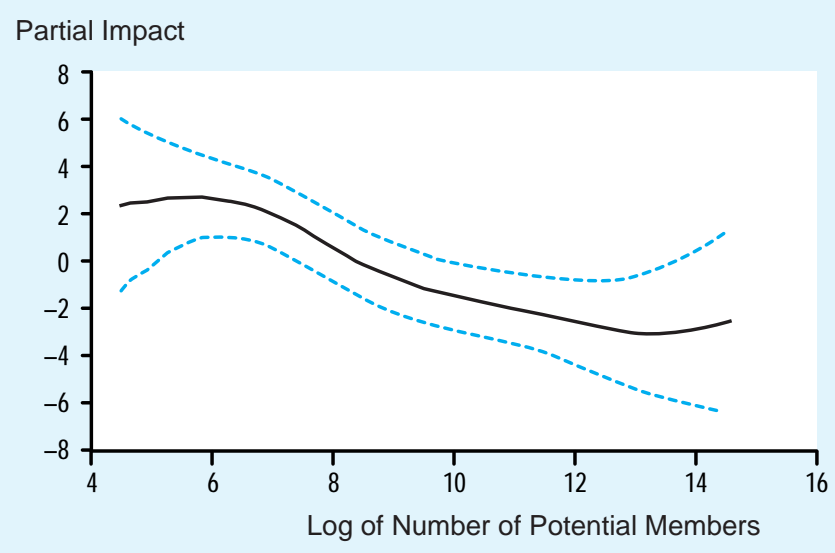

\section{Figure 7}

\section{Cost Ratio - Number of Members}

Partial Impact

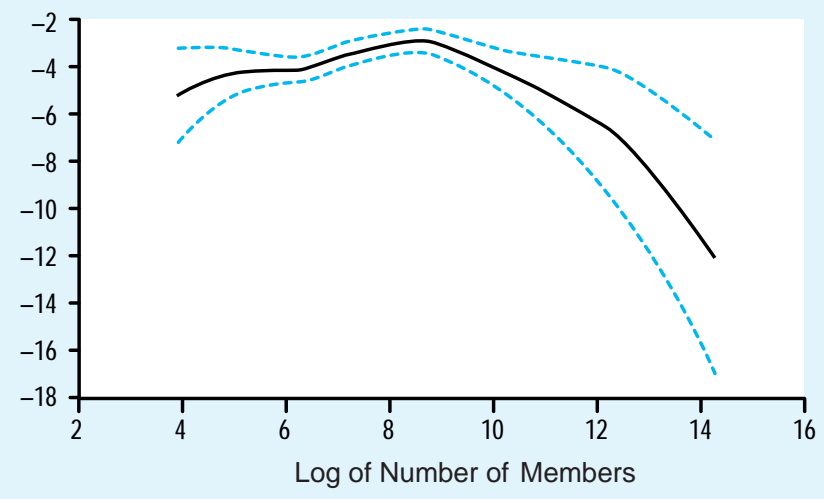

\section{Figure 8}

\section{Cost Ratio - Total Assets}

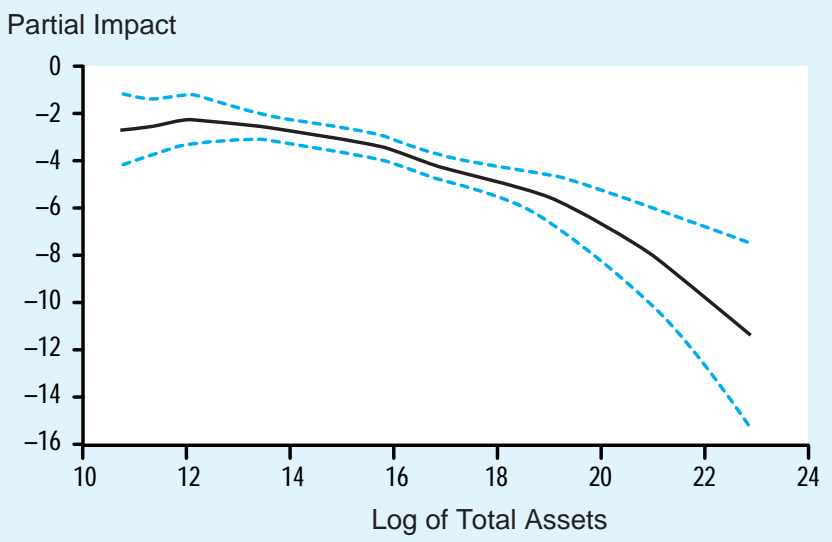


Table 5

Participation Rate

\begin{tabular}{lcc} 
Independent Variable & Coefficient & t-statistic \\
\hline MULTGROUP & $8.684 \times 10^{-2}$ & $2.834 * * *$ \\
HERF (lagged) & $3.628 \times 10^{-1}$ & $2.535 * *$ \\
REALGSPPC & -1.820 & -1.090 \\
POPDENS & $-3.743 \times 10^{-6}$ & -1.002 \\
TOM: Military & $2.266 \times 10^{-1}$ & $3.004 * * *$ \\
TOM: Government & $6.205 \times 10^{-2}$ & 1.496 \\
TOM: Manufacturing & $-2.123 \times 10^{-2}$ & -0.560 \\
TOM: Services & $1.304 \times 10^{-1}$ & $3.284 * * *$ \\
\hline Number of Observations & 4,691 &
\end{tabular}

$* *$ *** Significant at the $5 / 1$ percent level (two-tailed tests).

to focus on the slope of the curve and on the vertical differences moving along the horizontal axis. ${ }^{5}$

Figure 6 provides evidence supporting Hypothesis 1 (a negative relationship between participation rates and potential membership). The plot supports H ypothesis 1 because the lower confidence bound at small credit unions (small number of potential members) lies above the upper confidence bound for large credit unions, except for the very smallest and very largest credit unions, where the small number of observations widens the confidence intervals. This confirms our findings when we simulated the theoretical model (recall Figure 5) and is consistent with the idea that larger membership pools contain greater heterogeneity of preferences for banking services. This leads to greater differences in the most preferred bundle of banking services between the median member and members in the tails of the preference distribution.

An existing single-group credit union that adds one or more membership groups to its common bond encounters both benefits and costs of expansion. On the one hand, adding membership groups whose preferences are close to those in the existing field of membership (the back-to-back

${ }^{5}$ See Cleveland and Devin (1988). case) may increase the participation rate.

This outcome would be predicted as a result of a reduction in average operating costs and hence in the credit union's price of banking services. On the other hand, for a given credit-union charter, a higher number of potential members typically means more heterogeneity and thus a lower participation rate as the travel distance of the members located in the tails of the preference distribution increases.

Table 5 presents results from the parametric part of the model. The results provide evidence on the question of whether credit-union participation rates differ when comparing credit unions with a single common bond to those with multiple common bonds, holding all else equal. Recall from Tables 1 and 2 that credit unions with multiple-group charters will (on average) have higher participation rates than single-group credit unions if back-to-back membership combinations dominate (i.e., if there is a significant overlap of banking preferences among employees of different firms). Table 5 indicates that multiple-group credit unions in our sample indeed have higher participation rates, perhaps reflecting the ability of multiple-group credit unions to capitalize on similar preferences among employees of different firms.

Another interesting result in Table 5 is the positive and significant coefficient on the lagged Herfindahl index of bank deposit concentration in credit unions' local markets (Hypothesis 2). This indicates that, the more concentrated its local banking market is, the higher a credit union's participation rate will be. In other words, credit unions may provide an attractive alternative for consumers who face a relatively uncompetitive local banking market.

\section{Cost Ratio}

Hypotheses $3 \mathrm{a}$ and $3 \mathrm{~b}$ refer to tests of an important maintained assumption of our model, namely, that a credit union's operating expenses should decline with an increase in its scale of operation. We also would like to know whether serving multiple-group memberships is costly. 


\section{PEVIEW}

SEPTEMBER/ O CTOBER 1999

Figure 7 plots COST against the number of members, while holding the level of total assets constant at its median value in the sample. The plot shows that COST decreases sharply beyond a certain threshold level of membership. For small credit unions, average costs seem to increase slightly with the number of members. While wide confidence intervals indicate that in this range the relationship between average costs and number of members is estimated imprecisely, an initial increase in the average operating costs actually might be supported by the data. For small credit unions, subsidies (such as rent-free office space, volunteer workers, etc.) tend to be relatively more important than for large units. As these subsidies become less important for credit unions with higher numbers of members, measured operating costs might approach shadow operating costs. Overall, the findings support our maintained assumption of declining average costs as the scale of operations increases. Similar evidence is provided in Figure 8 , which is generated by the same regression that produced Figure 7. Figure 8 plots the influence of another measure of the size of operations, total assets, on the credit union's average operating costs ( $\mathrm{H}$ ypothesis $3 \mathrm{~b}$ ) while holding the number of members constant at its median value in the sample.

Table 6 presents results from the parametric part of the model. The results indicate that there is a positive relationship between the existence of multiple membership groups in a credit union and COST. One might think that multiple-group credit unions would have high cost ratios due to agency costs. According to this line of reasoning, as membership groups try to free-ride on each other's monitoring, supervision of management might be inefficiently low. As Emmons and Schmid (1999) show, however, there is no evidence of multiplegroup charters causing agency costs.

Finally, the significantly negative coefficient on the Herfindahl index in Table 6 implies that higher levels of bank concentration in a local market lead to lower levels of the cost ratio reported by credit unions.

\section{Table 6}

\begin{tabular}{lcc}
$\begin{array}{l}\text { Cost Ratio } \\
\text { Independent Variable }\end{array}$ & Coefficient & t-statistic \\
\hline MULTGROUP & $7.509 \times 10^{-2}$ & $6.847 * * *$ \\
HERF & $-1.813 \times 10^{-1}$ & $-3.427 * * *$ \\
GRREALGSP & $-8.448 \times 10^{-1}$ & $-2.377 * *$ \\
TOM: Military & $1.038 \times 10^{-1}$ & $4.533 * * *$ \\
TOM: Government & $1.149 \times 10^{-1}$ & $8.043 * * *$ \\
TOM: Manufacturing & $1.036 \times 10^{-1}$ & $7.444 * * *$ \\
TOM: Services & $8.915 \times 10^{-2}$ & $6.019 * * *$ \\
\hline Number of Observations & 4,733 & \\
$* * * * *$ Significant at the $5 / 1$ percent level (two-tailed tests). &
\end{tabular}

One possible explanation is that less intense competition from banks allows credit-union managers to enjoy a "quiet life." For example, credit unions may be able to attract or retain members with lower marketing efforts or lower quality services than would be the case in a more competitive market. On the other hand, the quiet life that comes with less competitive markets might allow greater scope for managerial agency costs. If the latter were the case, however, it would generate predictions opposite to our empirical findings of lower average operating expenses.

\section{CONCLUSIONS}

Continued expansion of credit unions has been accompanied by public debate and courtroom confrontations. Advocates argue that credit unions provide needed competition to banks and thrifts in local markets for retail financial services. Opponents, including most notably the banks and thrifts themselves, point to various subsidies to credit unions that create an unlevel playing field. Previous research findings do not provide unambiguous conclusions favorable to either camp, while recent federal legislation favorable to creditunion expansion merely has intensified the debate. More research into the fundamental operation of credit unions is needed. 
In this article, we investigate the relationships between several features of credit unions, namely the number of members in a credit union, the amount of total assets on its balance sheet, and the existence of single and multiple common bonds among its membership, on the one hand, and two measures of credit-union effectiveness, on the other. We also examine the effect of several environmental variables, including economic conditions and banking concentration in the local market, on credit-union operations.

We find that a larger potential creditunion membership translates into lower credit-union participation rates. Credit unions with multiple common bonds, holding all else constant, have higher participation rates. We also find evidence that credit unions in more concentrated banking markets exhibit higher participation rates.

W hile greater asset size appears to be associated with lower average operating costs, holding all else equal, we find that a larger number of members is associated with a lower cost ratio only for larger credit unions. Thus, asset size and the size of the membership are distinct aspects of creditunion operations. Multiple-group credit unions have higher costs on average, all else equal. We al so find that credit-union cost ratios are lower in more concentrated banking markets, perhaps indicating that credit unions can economize on marketing or service provision when competition from banks is less intense.

Our findings are particularly interesting in light of the recent AT\& T Family Credit Union case decided by the Supreme Court in February 1998, and its sequel in the U.S. Congress that culminated in the Credit Union Membership Access Act of August 1998. This new federal legislation upholds the right of federally chartered credit unions to grow under an expansive definition of the common-bond requirement. The new law allows multiple groups of members to belong to a single credit union as long as the members of each group are united by a common bond. This statute therefore upholds regulatory actions taken in recent years and overturns the Supreme Court's narrow reading of the 1934 Federal Credit Union Act restricting a federal credit union to a single common bond.

\section{REFERENCES}

American Bankers Association. The Credit Union Industry: Trends, Structure, and Competitiveness (Washington, D.C., 1989).

BNA Banking Report. "House Passes Credit Union Bill; Clinton Wastes No Time Signing It," August 10, 1998, Vol. 71, №. 6.

Cleveland, William S., and Susan J. Devlin. "Locally Weighted Regression: An Approach to Regression Analysis by Local Fitting," Journal of the American Statistical Association (September 1988), pp. 596-610.

Emmons, William R., and Frank A. Schmid. "Wages and Risk-Taking in Occupational Credit Unions: Theory and Evidence," this Review (March/ April 1999), pp.13-31.

Hotelling, Harold. "Stability in Competition," Economic Joumal, (March 1929), pp. 41-57.

Kane, Edward I., and Robert Hendershott. "The Federal Deposit Insurance Fund that Didn't Put a Bite on U.S. Taxpayers," Joumal of Banking and Finance (September 1996), pp. 1305-27.

Milgrom, Paul, and John Roberts. Economics, Organization and Management, Prentice Hall, 1992.

Supreme Court. "National Credit Union Administration, Petitioner, v. First National Bank \& Trust Co., et al.; AT\& T Family Federal Credit Union, et al., Petitioners, v. First National Bank and Trust Co., et al." Decided Feb. 25, 1998. Nos. 96-843, 96-847. 118 S. Ct. 927.

U. S. Treasury Department. Credit Unions, U.S. Government Printing Office, 1997. 


\section{REVIEW}

SEPTEMBER/ O CTOBER 1999

\section{Appendix}

\section{DATASET AND VARIABLES}

\section{The Dataset}

We analyze a dataset comprising all federally chartered and federally insured credit unions during the year 1996. The dataset was obtained from the Report of Condition and Income for Credit Unions (NCUA 5300, 5300S), produced by the National Credit Union Administration (NCUA). These reports are issued semiannually in June and December. We used the December data. The flows in the December income statements include the entire year of 1996.

We concentrate on the following Types Of Membership (TOM) groups among occupationally based credit unions: educational; military; federal, state, and local government; manufacturing; and services. This means that we do not include community credit unions, associational credit unions, or corporate credit unions.

Lists of TOM classification codes are from the NCUA (Instruction No. 6010.2, July 28, 1995).

We excluded observations for any of the following reasons:

- Missing TOM codes.

- Activity codes other than "active."

- Number of members or of potential members not greater than one; applies to actual and to lagged values.

- Nonpositive values for total assets or lagged total assets.

- Zero number of employees.

- Zero value for "employee compensation and benefits."

Total assets, number of members, potential number of members, and the Herfindahl index were all lagged one year (i.e., 1995 values). All other observations are from year-end 1996.

We calculated county-specific Herfindahl indexes as measures of concentration of the local banking market. A Herfindahl index is defined as the sum of squared market shares. We measured market shares by the fraction of total bank deposits (as of June 30 ) within a county based on FDIC Summary of Deposits data. These data are available online at বhttp://www2.fdic.gov/sod/>.

We used either the log level of Real Gross State Product (REALGSP) or its log growth rate to control for cross-sectional differences in macroeconomic conditions facing credit unions. The REALGSP data are in millions of chained 1992 dollars. We obtained the data from the U.S. Department of Commerce, Bureau of Economic Analysis, Regional Economic Analysis Division. The data are available online at «ttp://www.bea. doc.gov/bea/regional/data.htm>.

Population density at the county level was calculated by dividing the total county population by the total land area of the county (in square miles). Both the county population and land area data were obtained from the U.S. Census Bureau বhttp://www.census.gov>. The population data are Census Bureau estimates as of July 1,1996 . The land area measurements are from the 1990 census.

\section{Definition of Variables}

We transformed the dependent variables in some cases to ensure that they are not bounded. These transformations are necessitated by the assumption of normally distributed error terms. For variables that are restricted to the positive orthant of real numbers, we substitute their natural logarithms. For variables expressed as fractions (i.e., restricted to the interval $[0,1])$, we applied the logit transformation $\log (y /(1-y))$, with $\log$ being the natural $\log$ arithm. In this case, observations equal to one were eliminated from the set of observations; there were no cases in which the transformed variable equaled zero.

Definitions of variables and underlying data sources are listed below. For data taken from the Report of Condition and Income for Credit Unions, produced by the National Credit Union Administration, the relevant item numbers are in brackets. 
Dependent Variables. We employed two dependent variables in the regressions:

1) Participation Rate (PARTICIPATION):

N umber of actual credit-union members [CUSA6091] divided by the number of potential members [CUSA6092]. In the regressions, we use the logit transformation $\log (y /(1-y))$. No zero values for the number of members occurred. Fortytwo cases of full participation $(\mathrm{y}=1)$ were eliminated from the dataset for these regressions only.

2) Cost Ratio (COST): Total operating expenses [CUSA4130] divided by total assets [CUSA2170]. In the regression, we use log values.

Independent Variables. When total assets (measured in units of one dollar), the number of members, or the number of potential members served as regressors, they were lagged by one period and transformed into natural logarithms.

1. MULTGROUP: equal to one if the credit union has multiple groups; zero otherwise.

2. HERF : Sum of squared market shares of commercial banks within a county based on total bank deposits. By definition, the Herfindahl index is greater than zero; its maximum value is one.

3. REALGSPPC: Real gross state product per capita (chained 1992 dollars).

4. GRREALGSP: Logarithmic changes in the real gross state product (chained 1992 dollars).

5. POPDENS: Population Density, people per square mile in each local banking market.

6. TOM code variables: equal to one if the credit union is of a specific type (educational, military, government, manufacturing, or services). Because we use an intercept in (the nonparametric part of) the regression, the TOM code variable for the educational credit union was dropped. 